\title{
Classical Chinese Philosophy and the Concept of Qi
}

\author{
Filosofia chinesa clássica e o conceito de Qi.
}

\begin{abstract}
Jana S. Rošker ${ }^{1}$
${ }^{1}$ Professor of Sinology, Department of Asian Studies, Faculty of Art, University of Ljubljana (Slovenia). PhD degree obtained at the Vienna University in Austria. Co-founder and Head of the Department of Asian studies of the University of Ljubljana. E-mail: jana.Rosker@ff.uni-lj.si.
\end{abstract}

Recebido em 12 de maio de 2020; Aceito em 25 de outubro de 2020.

DOI: $10.12957 /$ nearco.2020.57698

\begin{abstract}
:
The concept of $q i$ 氣 belongs among the most difficult and complex notions in Chinese ideational history. The present article follows from recognizing that traditional translations of this concept are Eurocentric. The author substantiates the problematic role of these presumptive translations through critical analyses of their methodological approaches, which led to the traditional, falsified understanding of this concept. A new alternative and richer understanding of this concept is proposed, pointing to several different levels of meaning on which it can be understood. The author analyses and interprets the notion of $q i$ including its various philosophical, physiological, psychological end ethical dimensions. The article shows that on the semantical level, qi derives from the etymological meaning of air and is in essence similar to the concept of field in physics, referring to the breath as the origin of the living world. From this perspective, the holistic nature of this notion of breath will be introduced, exposing the dynamic network through which it connects all existing beings in the universe, endowed with life.
\end{abstract}

Keywords: qi, breath, Chinese philosophy

\section{Resumo:}

O conceito de qi 氣 está situado entre um das noções mais difíceis e complexas da história ideacional chinesa. O presente artigo parte do reconhecimento de que as traduções tradicionais desse conceito são eurocêntricas. A autora fundamenta o papel problemático dessas traduções presuntivas por meio de análises críticas de suas abordagens metodológicas, que levaram à compreensão tradicional e falsificada desse conceito. Uma nova alternativa e uma compreensão mais rica desse conceito é proposta, apontando os diversos níveis de significado nos quais ele pode ser compreendido. A autora analisa e interpreta a noção de qi, incluindo suas várias 
dimensões filosóficas, fisiológicas, psicológicas e éticas. O artigo mostra que, no nível semântico, qi deriva do significado etimológico de ar e é essencialmente semelhante ao conceito de campo na física, referindo-se à respiração como a origem do mundo vivo. Nessa perspectiva, será apresentada a natureza holística dessa noção de respiração, expondo a rede dinâmica por meio da qual ela conecta todos os seres existentes no universo, dotados de vida.

Palavras-chave: qi, respiração, filosofia chinesa

\section{Introduction}

Since the very early Chinese philosophic discourses, the notion of qi belonged to the most basic categories for the understanding of reality. It is already mentioned in the Guoyu 國語 (State Records), a work that goes back to ca 500 B.C. In this book, the notion qi apparently referred to an earthquake. According to this categorization, earthquakes were results of an imbalance of the tu qi 土氣 (the earthly qi). When the yang qi 陽氣 (the dynamic, active qi) was suppressed and could not get out, the situation resulted in the explosion of the tuqi (the qi of the earth). ${ }^{59}$

An earthquake, however, was only one of the many different ways of explaining natural events in terms of the dynamic of qi. The notion can already be found in the oracle inscriptions of the early Zhou Dynasty (1066 - 771 BC), symbolizing the cloudy vapors in the air (CHENG, 2003, p. 615). It contained the idea of air and was therefore mostly connected with the process of breathing. Hence, it is probably not coincidental that already in the sources from the 6th century B.C., the term qi is seen as the cause of natural events, and not only as a means to describe them. In this context, one can already distinguish various versions of the theory of qi, including a theory of its close connection to the interactions of the five powers (wu xing 五行) that create life and the universe. In its recent form, it is mostly applied in the compound kongqi 空氣, which

59 陽癉憤盈, 土氣震發 ... 自今至于初吉, 陽氣俱蒸, 土膏其動。“Guoyu 國語 (State Records),” Chinese Text Project: Pre-Qin and Han, accessed December 29, 2015, http://ctext.org/guo-yu . 
means air (in empty space). Hence, it is something that is physically real, but at the same time invisible.

In most traditional sources, the notion implied an organic state, linked to breath. Since the exchange of gases and oxygen underlies any form of life as we know it, qi is of fundamental and vital significance for any organic existence. This organic state is internalized in the human body, but simultaneously it connects all existing beings in the universe that are endowed with life. Such a notion of qi can be found, for instance, in Guanzi $^{60}$, in which we come across the notion of a quintessential qi (jing qi 精氣 ${ }^{61}$ ), which is responsible for life: things live because they have $q i^{62}$ - as soon as they lose it, they die ${ }^{63}$.

It thus manifests itself as the vital force that underlays any form of life, as the principle of vital creativity, as the cause of any change and transformation, which in Chinese philosophy thoroughly has been seen as the fundamental precondition of life. In the process of breathing, one can see the evidence of life. Breathing in air and breathing it out results in the circulation of blood in the body, and so qi implies the meaning of internal life force. This life force is by no means limited to the automatic bodily functions; on the contrary, it also produces consciousness and awareness, and thus comprises the very foundation for every form of knowledge and wisdom. Because it is the power of continuous change, it elevates and becomes a cosmic (and even cosmological) power of creation (GEANEY, 2002, p. 9).

Eventually, the concept of qi acquires the meaning of both energy or force and vitality, and thus becomes "vital energy" or "vital force", but it has not lost its

\footnotetext{
60 管子; an important political text written in the Spring and Autumn period (770 - 476 BC)

61 “Guanzi 館子 (Master Guan)," Chinese Text Project: Pre-Qin and Han, accessed December 29, 2015, http://ctext.org/guanzi.

62 坦氣修通, 凡物開靜, 形生理。Ibid.

63 有氣則生, 無氣則死。Ibid.
} 
naturalistic or even materialistic reference of meaning. In fact, what we have observed about the visible natural qi can be extended to the invisible internal qi of an organism. It is even extended to the atmosphere - which is invisible but can be experienced. ${ }^{64}$

In the human body, however, qi's activity does not remain limited to the function of breathing. It underlies every function of all organs, of blood and seminal fluids. It is also closely connected with the very bases of traditional Chinese medicine, for it also underlies the invisible electric neural currents that represent the foundation for healing various diseases with acupuncture, acupressure, or with the help of psychosomatic exercises.

Although in ancient sources, the concept of qi has thus almost exclusively been associated with the meaning of some kind of vital power or vital energy, it appeared often as "matter" in the earliest French and English translations. This erroneous understanding is connected to some general problems of intercultural understandings. In order to understand the reasons for such misinterpretations of the notion qi, we must take a brief look into some important distinctions that mark the fundamental and paradigmatic differences between the European and the Chinese philosophies.

\section{Some general problems of intercultural interpretations in Chinese studies}

Philosophic discourses from traditional China differ from those that have prevailed in the course of European ideational history in their basic paradigms. In this context, we must expose the principle of transcendence in immanence, which is essentially different from basic approaches applied in transcendental metaphysics. On the one hand, immanent, but simultaneously transcendent notions are doubtless a

64 “Guanzi 館子 (Master Guan).” 
NEARCD: Revista Eletrônica de Antiguidade 2020, Volume XII, Número II - ISSN IS82-8713

Núcleo de Estudas da Antiguidade - NEA

Universidade do Estado do Rio de Janeiro

ISSN 1982-8713

necessary product of the classical Chinese holistic worldview. This is also the reason that the prevailing ideational discourses in traditional China did not create a notion of "pure transcendence" in the sense of exceeding one and transferring into another (usually 'higher') sphere of meta-physical noumena. Such a holistic worldview is rooted in relations of antagonistic binary notions that are often named binary categories (duili fanchou 對立範疇). The mutual interactions between the two poles that form such a category are governed by the principle of correlative complementarity, which belongs to the fundamental paradigms of Chinese reasoning and which, inter alia, led to the formation of patterns of specific Chinese analogous reasoning.

Nevertheless, this holistic worldview was rigidly structured; it was by no means a homogenous unity in which everything was connected to everything else, without distinctions or demarcations. The classical Chinese worldview was thus logically ordered and its order was based on relatively strict binary oppositional patterns. Hence, the above-mentioned binary categories belong to the basic features of traditional Chinese philosophy. Such categories can be seen as dualities that seek to attain a state of actuality through relativity, which is expressed through the relation between two oppositional notions ${ }^{65}$.

Distinctions are seen in binary terms, and primarily between pairs of opposites (with even figure and color reduced to square/round and white/black); having drawn them, and recognized some recurring or persisting pattern (for example large, round, hard, heavy, and white), we detach a stone from other things as we cut out a piece of cloth or chop off a piece of meat. Things are not seen as isolated, each with its own essential and accidental properties; on the contrary, distinguishing characteristics are seen as mostly relative (GRAHAM, 1989, p. 286).

However, it is completely clear that as such, binary patterns are not only a specific characteristic of Chinese philosophy; in their divisional effect, they create a basic

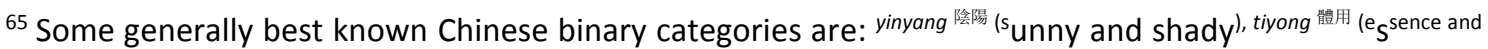
function), mingshi 名實 (concept and actuality), liqi 理㲷 (structure and phenomena), benmo 本末 (roots and crown), etc.
} 
condition for any form of human thought. Binary patterns have led to many various modes of reasoning.

One of them can be found in the model of Cartesian dualisms, which prevailed in pre-modern and modern Euro-American thought. The model that prevailed in Chinese ideational history differs in many aspects from these dualisms. A basic distinction between the two modes of binary reasoning is rooted in the aforementioned principle of complementarity, which governs the Chinese model. The dualistic model, as prevailed in Western philosophy, involves a dialectics posited upon the relation between the mutually exclusive and polar opposites of thesis and antithesis, which are in mutual contradiction. This contradiction forms a tension, in which the mutual negation of thesis and antithesis creates a synthesis. The complementary model, on the other hand, is instead based upon a non-contradictory opposition between the two anti-poles, which do not exclude, but rather complement each other, and which are also interdependent (ROŠKER, 2012, p. 280). Such dual patterns cannot produce any separate synthesis in which the 'positive' elements of the previous state could be preserved, while the 'negative' ones would be eliminated. The Daoist philosopher Zhuangzi described such a binary relation as follows:

This is why I am saying: why cannot we preserve truth and eliminate falseness? Why cannot we preserve order and eliminate chaos? Such thinking means that we do not understand the structure of nature, nor the state of being in which everything exists. This would mean preserving earth and eliminating heaven, preserving yin and eliminating yang. It is completely clear that this could not work. ${ }^{66}$

\footnotetext{
66 故日: 蓋師是而無非, 師治而無亂乎? 是未明天地之理, 萬物之情者也。是猶師天而無地, 師 陰而無陽, 其不可行明矣。“Zhuangzi 莊子 (Master Zhuang),” Chinese Text Project: Pre-Qin and Han, accessed December 29, 2015, http://ctext.org/zhuangzi.
} 
ISSN 1982-8713

Such explanations of binary relations differ to a great extent from logocentric dualisms as were developed in the Hellenistic and Judeo-Christian traditions. The latter were namely based on mutual contradiction of the two anti-poles, tending to preserve one of the poles while abolishing the other. The most important specific features of complementary relations that distinguish them from the Cartesian type of dualisms are thus the non-contradictional opposition of the two anti-poles, their interdependence, their axiological equality, and their mutual supplementation.

What is important for our present study of the notion of qi, however, is the fact that such binary patterns also became visible in the basic paradigms, which defined the medieval and pre-modern Chinese cosmology. This cosmological (or ontological) paradigms were expressed through the mutually complementary interactions between the principles of $l i$ 理 and qi, whereby the former was understood as structure (or structural patterns) and the latter as (vital) creativeness. Hence, even though this cosmological system was binarily ordered, it is important to know that traditional Chinese thinkers never strictly distinguished between the spheres of matter and idea, or any other dualistic connotations resulting from this basic dichotomy ${ }^{67}$. In the system of classical Chinese cosmology, the world was not composed by matter and idea, or by material and ideational elements. It was created through correlative interactions between the dynamic, all-encompassing structural patterns li that were mutually compatible with and endowed with life through the vital potential or vital force(s) qi. ${ }^{68}$

While in ancient and early medieval China, the notion of qi has mostly been applied in the sense of an independent concept, things changed in later medieval and pre-modern China. In the scope of the Neo-Confucian philosophies of the Song (960 1279) and Ming (1368 - 1644) Dynasties, it was seen as a part of the bipolar (or binary)

\footnotetext{
${ }^{67}$ As, for instance, distinctions between subject and object, substance and phenomena, creator and creation, etc.

${ }^{68}$ See Rošker, "Structure and Creativeness," p. 280.
} 
NEARCD: Revista Eletrônica de Antiguidade 2020, Volume XII, Número II - ISSN IS882-8713

Núcleo de Estudas da Antiguidade - NEA

Universidade do Estado do Rio de Janeiro

ISSN 1982-8713

category of structure (li) and creativeness (qi), which represented the basic cosmological pair that underlays every form of existence. ${ }^{69}$

\section{The binary relation between $q i$ and $l i$ and false interpretations of the notion qi}

When the first sinologists (who were mostly Christian missionaries) initially came to China in the 17th century, the prevailing ideology they encountered was based on the Neo-Confucian philosophy. Hence, for them, it was perfectly natural to interpret its bipolar conception of the world, consisting of something called qi and organized in accordance with something else called li, in terms of, respectively, matter and idea. However, in our view, the concept li cannot be understood as idea or principle in the "Western" sense, but rather as structure or a structural pattern, which can, of course, also pertain to the sphere of abstractions or ideas. Similarly, and based on a more profound understanding of Neo-Confucian philosophy, it is evident that the concept qi can hardly be understood as matter in the "Western" sense. In fact, the Neo-Confucian philosophers defined it as something that is not necessarily substantial, for air or even a vacuum (the great void tai $x u$ 太虛) are composed of it. Thus, it represents a concept that could be more appropriately defined as creativity, or a potential that functions in a creative way. Hence, Zhang Zai (1020-1077), a pioneer of the neo-Confucian thought,

\footnotetext{
${ }^{69}$ In the philosophy of Zhu Xi 朱喜 (1130-1200), who is the most well-known representative of the NeoConfucian discourses, the binary patterns tended to transform into a semi-dualistic pattern (see Jana $\mathrm{S}$. Rošker, The rebirth of the moral self: The second generation of modern Confucians and their modernization discourses (Hong Kong: Chinese University Press, cop. 2016), xx) because they relied too heavily on a mechanistic rationality. Such approaches resulted in a deformation of the holistic tradition in philosophy, in which the binary poles of structure (li) and vital creativity (qi) were harmonized, thereby preserving the harmonic unity of facts, values, and the sphere of aesthetic experience. Hence, numerous scholars share the opinion that Neo-Confucian philosophers headed by Zhu Xi represented a turnaround in Chinese tradition. This was often expressed through the optics of its alleged "germs of dualism" (see for instance Alfred Forke, Geschichte der mittelalterlichen Chinesischen Philosophie II, Hamburg: R.Oldenbourg, 1934b, p. 173). However, it was still a mixture between both models; and what matters most in the context of the present study is the fact that, even in their function of basic cosmological elements, $l i$ and qi were never seen as idea and matter respectively by any of the traditional Chinese philosophers - including Zhu Xi.
} 
NEARCD: Revista Eletrônica de Antiguidade 2020, Volume XII, Número II - ISSN IS882-8713

Núcleo de Estudas da Antiguidade - NEA

Universidade do Estado do Rio de Janeiro

ISSN 1982-8713

described it in the following way: "In the great void, qi condenses and dissolves again. This can be compared to ice dissolving in water". ${ }^{70}$

According to most traditional Chinese interpretations, in its condensed form qi pertains to the sphere of matter, whereby it belongs to the sphere of abstract entities in its finest, most dispersed state ${ }^{71}$. However, the majority of traditional European and American sinologists have (as we have noted above) translated this concept as matter. To illustrate this point, we can cite the translation of the above quoted passage by the renowned French sinologist from the beginning of the 19th century, Le Gall (1858-1916), in which the notion $q i$ is clearly understood as atom(s): "Le condensation et les dispersions des atomes dans la T'ai-hiu peuvent se comparer a la fonte de la glace dans l'eau" (LE GALL, 2006, p. 49).

This translation of the concept $q i$ is problematic, for it derives from a profoundly intrinsic sense of the criteria, based upon the model of Cartesian dualism. Although Zhang Zai's comparison with water explicitly states that $q i$ is a continuous state, and not an aggregate of atoms, the analogy with matter was so deeply rooted in Le Gall's perception that he automatically saw the notion qi as an entity, which contains or is composed of atoms. Hence, for centuries, Le Gall and other sinologists who followed his reading have misled scholars regarding the question whether traditional Chinese philosophy applied the concept of atomicity (GRAHAM, 1989, p. 61).

The second term, or the concept $l i$, indicates the notion of structure, a structural pattern and the structural order of things. Taken as a whole, li represents a cosmic

\footnotetext{
70 氣之聚散於太虛由冰釋於水. Zhang Zai 張載, 正蒙 Correction of Ignorance, in Xingli da quan 4: Kongzi wenhua da quan, edited by Hu Guang Jinan: Shandong youyi shushe, 1989, p. 389.

${ }^{71}$ Huainanzi, a Han period (206 B.C.-A.D. 8) Taoist-oriented master of Chinese philosophy, said that before the birth of Heaven and Earth, there was only a formless, fluid state called taizhao, like a clear transparent void. This void, which is the beginning of Tao, gave birth to the universe. The universe in turn produced qi. That part of qi which was light and limpid, floated up to form Heaven, whereas the part of qi which was heavy and turbid coagulated to become Earth. Therefore, qi can be understood as protomaterial, a vital creative force that gives "form" to everything in the universe (XU, 1999, p. 967).
} 
pattern, defining lines of movement or the dynamicity of men and nature. These structural lines are seen as relations that define both the sphere of ideas and that of phenomena. At the same time, they make possible the mutual adjustment of binary oppositions with complementary functions, as well as their orderly fusion within cosmic unity.

The concept $l i$ is not obeyed or violated like a law; instead, one either goes with or against the grain of it, as in chopping wood. Le Gall translated it as forme, thus remolding the whole neo-Confucian cosmology after the analogy of Aristotelian form and matter (atoms). J. Percy Bruce instead translated this term as 'law', thereby incorporating into neo-Confucian terminology itself the wrong answer to the question 'Are there laws of nature in China?' ((GRAHAM, 1989, p. 61).

Instead, in these Neo-Confucian discourses, $l i$ and $q i$ are complementary concepts, which can be explained as a structure (or structural pattern) and a creative formative potential (creativity). Both are of immanent nature and can therefore be realized in the spheres of both ideas and phenomena. Euro-American philosophy offers no precise equivalents for these two terms. If we want to comprehend the modes of their existence and their functions, we must first free ourselves from reasoning in terms of Cartesian dualisms and try thinking based on the model of analogy, which arose from and was prevalent in the immanent metaphysic of traditional Chinese thought.

\section{The meaning of qi on different levels}

A.C. Graham points out that unlike the concept $l i$ that can mostly be expressed only on a metaphorical level, qi is quite concrete (GRAHAM, 1989, p. 62), since it really is - among other things - the breath in our throats. However, as already mentioned, the notion of qi had mostly been applied as an independent concept long before the NeoConfucian discourses. Already in Laozi's Dao de jing we come across passages that emphasize that concentrating on the natural flow of their breath enables human beings to remember their elementary nature and to become aware of their inseparable unity 
with the universe. "When people give undivided attention to the (vital) breath, and brings it to the utmost degree of pliancy, they can become as (tender) babes." 72 This connection between breath and mind was seen as important, because "the heart-mind can make the vital force (or breath of life) strong." 73

$Q i$ is the source of life, dispersing into the air at death. Hence, Qi was not only seen as human breath, but also as the breath of the universe: "When the cosmic breath comes strongly, it is called wind." 74

In addition to its fundamental meaning of human and simultaneously cosmic breath, the notion of $q i$ has several different semantic connotations, which differ according to the referential framework in which it has been applied. These frameworks pertain to various fields, as for instance philosophy, physics, physiology, psychology, ethics, aesthetics, and so on.

The relationship between $q i$ and human life in communities is evident in many East Asian socio-political, cultural, economic, and medical institutions. Based on this relation, a vernacular epistemology has been developed. Such an epistemology provides spiritual guidance for cultural, political, and economic conventions and everyday behavior (SHENG KUAN CHUNG, 2006, p. 34). "All that exists bears yin and embraces yang. Everything is infused with the breath of life to achieve harmony." 75 Hence, it is by no means coincidental that examples of disciplines and practices associated with $q i$ include the martial arts, traditional Chinese medicine, architecture, agriculture, aesthetic production, etc.

\footnotetext{
72 專氣致柔, 能嬰兒乎 ? “Laozi 老子: Daode jing 道德經 (The Book of Dao in and the Power of Virtue),” Chinese Text Project: Pre-Qin and Han, accessed December 29, 2015, http://ctext.org/dao-de-jing.

73 心使氣曰強. Ibid., 55.

74 夫大塊噫氣, 其名為風。“Zhuangzi 莊子 (Master Zhuang)."

75 萬物負陰而抱陽, 沖氣以為和。“Laozi 老子: Daode jing 道德經 (The Book of Dao in and the Power of Virtue)," 42.
} 
NEARCD: Revista Eletrônica de Antiguidade 2020, Volume XII, Número II - ISSN IS882-8713

Núclea de Estudas da Antiguidade - NEA

Universidade do Estado do Rio de Janeiro

ISSN 1982-8713

On the philosophical level, qi can be compared to all sorts of gas, and especially to air, which is indispensable for the breathing ${ }^{76}$. This basic connotation which is tightly linked to the process of breathing in the sense of the most fundamental vital function of all life, will be explored a bit more in detail in the next section. However, in order to gain an idea of the wide ranged complexity of the term, let us first take a brief look to the meanings of qi in other significant fields of knowledge.

In physics, $q i$ is similar to the idea of field. This idea has gained special importance in various practices of the bodily qi-cultivation, which was based upon the so-called qigong 氣功 exercises. A qi field (qi chang 氣場) refers to the cultivation of an energy field that can allegedly be used for various healing or other benevolent purposes. In such practices, which are very popular in contemporary China, a qi field is believed to be produced by breath control, visualization, and affirmation. All these techniques are psychological tools for observing the magnetic field that is a part of every organic entity. ${ }^{77}$

In traditional Chinese medicine it represents a form of wind ${ }^{78}$ and the vital force, which makes any form of organic life possible. In traditional medical discourses, the concept of qi was often applied together with the term xue 血,which means blood. The term xueqi 血氣 was developed to express the essential function of the blood as it

\footnotetext{
${ }^{76}$ See for instance the Confucian Analects: ...屏氣似不息者。(...holding in his breath, as if he dared not breathe) (“Lunyu 論語 (The Analects)," Chinese Text Project: Pre-Qin and Han, accessed December 29, 2015, http://ctext.org/analects.)

${ }^{77}$ See Cunshan Li 李存山, “Qi, shiti yu changyou 氣, 實體與場有(Qi, Substance and Field),” in Chang yu you - Zhongwai zhexuede bijiao yu rongtong. Field and Being: the Comparison and Fusion of Chinese and non-Chinese Philosophies, ed. Luo Jiachang and Zheng Jiadong. Beijing: Dongfan chuban she, 1994, p. 132.

${ }^{78}$ Just as traditional Chinese cosmogony holds that everything is produced through the movement and transformation of qi, so traditional Chinese medicine explains life as a concentration of this primal or vital potential. "The complications of the Chinese medical theory of $q i$, as articulated through the scheme of yin and yang, and the five powers (wuxing 五行), were basically derived from this fundamental understanding". The method of analyzing the factors of illness focuses almost exclusively on the war between heteropathic and orthopathic qi, the relations between climate or other environmental excesses (e.g. of heat, damp, wind) and physiological heat, damp, or sluggishness. See HSU, 2007, p. 117.
} 
NEARCD: Revista Eletrônica de Antiguidade 2020, Volume XII, Número II - ISSN IS82-8713

Núcleo de Estudas da Antiguidade - NEA

Universidade do Estado do Rio de Janeiro

ISSN 1982-8713

coursed through the arteries, bringing nutrients to the remotest parts of the body (ZHANG; KEN, 2001, p. 7). Hence, it often appears as the elementary source of vital energy, which preconditions every social activity: "They tasked their blood and breath to make out a code of laws." 79

This relation between the qi and blood was already clearly defined in the ancient medical book entitled The Yellow Emperor's Classic of Internal Medicine (黃帝內經). Their inseparable connection was seen as a necessary precondition for any form of life: "Blood and qi constitute human spirit. Therefore, they have to be cherished and cultivated." 80

It was perhaps the recognition of this intimate relationship between qi and blood that provided ancient theorists with the understanding necessary to construct a map of the pathways both these essential substances traversed throughout the entire human body. The deceptively simple phrase xue qi contains the gist of this interrelationship (ZHANG; KEN, 2001, p. 7).

But Confucius, on the other hand, often used the term xueqi in the sense of the (male?) sexual potential:

There are three things the superior man guards against: in youth, when the sexual powers are not yet settled, he guards against lust. When he is strong and his sexual powers are full of vitality, he guards against pugnacity. When he is old, and his sexual powers are decayed, he guards against lust. ${ }^{81}$

Shén qi 神氣 is another important compound applied in traditional Chinese medicine. The term shen connects qi with another of the essential entities indispensable to life itself. Shen means "spirit" and it reflects the belief of the ancient Chinese healers

\footnotetext{
79 矜其血氣以規法度。“Zhuangzi 莊子 (Master Zhuang).”

${ }^{80}$ 血氣者, 人之神, 不可不謹養。“Huangdi neijing 黃帝內經 (The Yellow Emperor’s Classic of Internal Medicine)," Chinese Text Project: Pre-Qin and Han, accessed September 21, 2015, http://ctext.org/huangdi-neijing.

81 君子有三戒: 少之時, 血氣未定, 戒之在色; 及其壯也, 血氣方剛, 戒之在罜; 及其老也, 血 氣既衰, 戒之在得。“Lunyu 論語 (The Analects).”
} 
that human beings contain a spark of the eternal, which is indispensable for their existence. "Yet even this eternal flame could not burn without an invisible but essential substance, the breath of life: qi." 82 Hence, the phrase shén qi represented the medical concept of spirit, i.e., of human innermost vitality. Zhuangzi, the most radical opponent of orthodox Confucianism, applies this term in the context of criticizing their shallow ambitions linked to their obsession with various techniques of body and mind cultivation. In his chapter On Heaven and Earth a simple gardener warns Zi Gong子貢, one of Confucius' most famous disciples of, of excessively controlling the spirit and being excessively obsessed with the ancient "fitness" by saying: "You should forget the energy of your spirit, and neglect the care of your body." 83

$Q i$ is also an important notion within traditional Chinese aesthetics, including paintings, architecture, literature, music, and dance. All forms of Chinese art seem to be closely integrated and interrelated by qi. Calligraphy, for instance, is driven by "the pulse of qi" (ZHANG; KEN, 2001, p. 61). In paintings, this pulse develops into "the charm of qi." Similarly, literary expressions are also connected with the concept of qi and can be divided into two categories. Prose is usually motivated by "the momentum of qi" and poetry by its "romantic charm." All these elements develop the aesthetic sense and function on many different levels of beauty appreciation.

\section{Qi as the breath and the source of life}

In Chinese philosophy, the world was seen to be in constant motion, manifesting the changes of life. All these changes and movements were rooted in qi. Hence, this notion could be applied to explain all transformations and developments. Thus, it is by no means coincidental that it holds a premier position in classical Chinese thought. As

\footnotetext{
82 Ibid., 6.

83 汝方將忘汝神氣, 墮汝形骸! “Zhuangzi 莊子 (Master Zhuang).”
} 
NEARCD: Revista Eletrônica de Antiguidade 2020, Volume XII, Número II - ISSN IS82-8713

Núcleo de Estudas da Antiguidade - NEA

Universidade do Estado do Rio de Janeiro

ISSN 1982-8713

we have seen, $q i$ is the principal source of energy and matter, establishing simultaneously the elementary spirit of all human beings (ZHANG; KEN, 2001, p. 61-62). Therefore, qi was also seen as a connective medium through which living beings could harmonize their growth and development and become aware of their inherent connection with the forces of nature. The elementary meaning of qi is revealed through the holistic understanding of breath, which exposes the dynamic network connecting all existing beings in the universe, endowed with life.

This aspect is already visible in the earliest etymological explanation of the Chinese character, which expresses the notion. It was created as a semantic compound, consisting of the element 气, which originally depicted the shape of (rising) clouds ZHANG; KEN, 2001, p. 3), and the radical 米, which means rice. According to some interpretations, ${ }^{84}$ its earliest forms in the oracle inscriptions of the early Zhou Dynasty (1066 - 771 BC), symbolize the cloudy vapors in the air. ${ }^{85}$ Zhuangzi applies the notion qi in this sense very often, for instance:

On a whirlwind it mounts upwards as on the whorls of a goat's horn for 90,000 $l i$, till, far removed from the cloudy vapours, it bears on its back the blue sky, and then it shapes its course for the South, and proceeds to the ocean there ${ }^{86}$. ... (He) mounted on the clouds, drove along the flying dragons ${ }^{87}$.... Being such, he mounts on the clouds of the air, rides on the sun and moon, and rambles at ease beyond the four seas. ${ }^{88}$

\footnotetext{
${ }^{84}$ See for instance Cheng, “Qi (Ch'i)," p. 615.

${ }^{85}$ Cheng, “Qi (Ch'i),” p. 615.

86 翼若垂天之雲, 摶扶搖羊角而上者九萬里, 絕雲氣, 負青天, 然後圖南, 且適南冥也。 “Zhuangzi 莊子 (Master Zhuang)."

87 乘雲氣, 御飛龍 Ibid., 5 .

88 若然者, 乘雲氣, 騎日月, 而遊乎四海之外。I bid.
} 
NEARCD: Revista Eletrônica de Antiguidade 2020, Volume XII, Número II - ISSN IS882-8713

Núcleo de Estudas da Antiguidade - NEA

Universidade do Estado do Rio de Janeiro

ISSN 1982-8713

The final ideogram 氣 suggests vapors rising from rice paddies. Such interpretations point out that the notion qi belongs to the typical terms of early agricultural China. ${ }^{89}$ According to some other interpretations that are based on definitions from the Shuowen jieci 說文解字 (Explaining Graphs and Analysing Characters), an early 2nd-century etymological dictionary, rather suggest that it depicts a man blowing on rice ${ }^{90}$, and that it means gas or breath. Such interpretations simultaneously point out the nourishing function of the concept qi. In later dictionaries, it is often explicitly linked to the term breathing ${ }^{91}$. This additional meaning came following the Yin (1600 - 1066 BC) and Zhou (1066 - 256 BC) periods. In this sense, it is already defined in the ancient Confucian classics, the Book of Rites ( $L i j i$ 禮記). In the course of later development, an alternate mode of writing the word qi developed and was used to express this meaning of breath. The character 互, (with the same pronunciation) meant "the qi of breathing." This way of writing was primarily used by Daoists and practitioners of various arts related to the cultivation of qi (ZHANG; KEN, 2001, p. 4-5).

It is interesting that this feature of the concept $q i$ is bearing many resemblances to several similar notions that were developed in other ancient cultures.

The ancient Hindus wrote of prana, the invisible "breath of life" that they cultivated through Yoga. Ancient Greeks described a concept which in several important aspects parallel the Chinese notion of qi with the word "pneuma." Like the Chinese qi, this Greek word is often translated into English as "breath" - with similarly misleading results. The Greek pneuma, like the Chinese concept of qi, was a complex idea that blended spiritual and material aspects of the vital essence of life into a comprehensive description of that without which life itself could not exist (ZHANG; KEN, 2001, p. 15).

\footnotetext{
${ }^{89}$ Cheng, “Qi (Ch'i),” 615.

90 饋客忽米也

${ }^{91}$ See for instance the Guangyun 廣韻 dictionary from the 10th century: 氣: 氣息也，
} 
ISSN 1982-8713

\section{Conclusion}

One must rely on qi in order to live and to grow strong. Sickness decreases qi and death depletes it. If humans do not drink for days or eat for weeks, they still might not die; but they will surely die from not breathing qi for less than an hour. Hence, qi was seen as something immensely precious, as the fundamental precondition of life.

In ancient Chinese philosophy, $q i$ is thus a limitless source of all creation forming an omnipresent cosmic creative flow. Since the ancient Chinese worldview was holistic, and based upon an inseparable unification of heaven (or nature) and men (天人合一), this creative flow is visible in both cosmic and human breath. In this sense, $q i$ is a basic vital rhythm connecting everything that exists in the great symphony of life.

\section{References}

CHENG, CHUNG-YING. Qi (Ch'i): Vital Force. In: CUA, Antonio S. (ed.). Encyclopedia of Chinese Philosophy. New York and London: Routledge, 2003, p. 615-617.

FORKE, Alfred. Geschichte der mittelalterlichen Chinesischen Philosophie II. Hamburg: R.Oldenbourg, 1934b.

GEANEY, Jane. Epistemology of the Senses in Early Chinese Thought. Honolulu: University of Hawai'l press, 2002.

GRAHAM, Agnus C. Disputers of the Tao - Philosophical Argument in Ancient China. Chicago: Open Court Publishing, 1989.

Guanzi 館子 (Master Guan). In: Chinese Text Project: Pre-Qin and Han. Available in: http://ctext.org/guanzi. Accessed December 29, 2015.

“Guoyu 國語 (State Records)." In: Chinese Text Project: Pre-Qin and Han. Available in: http://ctext.org/guo-yu. Accessed December 29, 2015. 
HSU, Elisabeth. The Experience of Wind in Early and Medieval Chinese Medicine. In: Wind, Life, Health: Anthropological and Historical Perspectives. The Journal of the Royal Anthropological Institute, 13 (2007), p. 117-134.

Huangdi neijing 黃帝內經 (The Yellow Emperor's Classic of Internal Medicine). In Chinese Text Project: Pre-Qin and Han. http://ctext.org/huangdi-neijing. Accessed September 21, 2015.

“Laozi 老子: Daode jing 道德經 (The Book of Dao in and the Power of Virtue). In: Chinese Text Project: Pre-Qin and Han. http://ctext.org/dao-de-jing. Accessed December 29, 2015.

LE GALL, Stanislas P. Le philosophe tchou hi, sa doctrine, son influence. Ville de Saguenay: Chicoutimi, 2006.

LI CUNSHAN 李存山. Qi, shiti yu changyou 氣, 實體與場有(Qi, Substance and Field). In: JIACHANG, Luo; JIADONG, Zheng (eds.). Chang yu you - Zhongwai zhexuede bijiao yu rongtong (Field and Being: the Comparison and Fusion of Chinese and non-Chinese Philosophies). Beijing: Dongfan chuban she, 1994, p. 123-135.

Lunyu 論語 (The Analects). In: Chinese Text Project: Pre-Qin and Han. http://ctext.org/analects. Accessed December 29, 2015.

ROŠKER, Jana S. Structure and Creativeness: a Reinterpretation of the Neo-Confucian binary category Li and Qi. In: GORDON, Richard; SECKBACH, Jeseph; SWAN, Liz (eds.). Origin(s) of Design in Nature: a Fresh, Interdisciplinary Look at how Design Emerges in Complex Systems, Especially Life, (Cellular Origin, Life in Extreme Habitats and Astrobiology 23). Dordrecht [et. el.]: Springer, 2012, p. 273-285.

ROŠKER, Jana S. The rebirth of the moral self: The second generation of modern Confucians and their modernization discourses. Hong Kong: Chinese University Press, cop. 2016.

SHENG KUAN CHUNG. Aesthetic Practice and Spirituality: "Chi" in Traditional East Asian Brushwork. Art Education 59, no. 4, 2006, p. 33-38.

$\mathrm{XU}$, JIAN. Body, Discourse, and the Cultural Politics of Contemporary Chinese Qigong. The Journal of Asian Studies 58, no. 4, 1999, p. 961-991.

ZHANG, Yu Huan, and KEN, Rose. A Brief History of Qi. Brookline: Paradigm Publications, 2001. 
NEARCD: Revista Eletrônica de Antiguidade 2020, Volume XII, Número II - ISSN IS82-8713

Núcleo de Estudas da Antiguidade - NEA

Universidade do Estado do Rio de Janeiro

ISSN 1982-8713

ZHANG ZAI 張載. 正蒙 Correction of Ignorance. In: HU GUANG (ed.). Xingli da quan 4: Kongzi wenhua da quan. Jinan: Shandong youyi shushe, 1989.

“Zhuangzi 莊子 (Master Zhuang)." In Chinese Text Project: Pre-Qin and Han. http://ctext.org/zhuangzi. Accessed December 29, 2015. 